\title{
Review
}

\section{Lessons from the NOD mouse for the pathogenesis and immunotherapy of human Type 1 (insulin-dependent) diabetes mellitus}

\author{
E.F.Lampeter ${ }^{1,3}$, A. Signore ${ }^{2,4}$, E. A. M. Gale ${ }^{1}$ and P.Pozzilli, ${ }^{1,4}$. \\ ${ }^{1}$ Department of Diabetes and Immunogenetics, St. Bartholomew's Hospital, \\ ${ }^{2}$ ICRF, HTIG, Faculty of Clinical Sciences, University College London, UK, \\ ${ }^{3}$ City Hospital Leipzig, Hospital of Internal Medicine, Leipzig, GDR, and \\ ${ }^{4}$ Cattedra Endocrinologia (I), Clinica Medica (II), University of Rome "La Sapienza", Rome, Italy
}

\begin{abstract}
Summary. Suitable animal models of human Type 1 (insulindependent) diabetes mellitus have long been sought, in particular a model that would permit detailed histological and immunological investigation of changes in the islet preceding the metabolic disorder. This would allow hypotheses as to pathogenesis of the condition to be examined and interventions such as immunotherapy to be tested. The most widely studied models include the low-dose streptozotocin induced diabetic mouse and the BB rat, but both differ in important respects
\end{abstract}

from the human disease. In this review we describe one highly successful model, the non obese diabetic mouse. Selected aspects of pathogenesis and immunotherapy are presented and analogies with human Type 1 diabetes discussed.

Key words: Non obese diabetic (NOD) mouse, pathogenesis Type 1 (insulin-dependent) diabetes mellitus, immunotherapy Type 1 diabetes.
The NOD mouse was derived from a cataract-developing substrain of the outbred JcI-ICR mouse by selective breeding from 1974 to 1980 [1]. Diabetes develops spontaneously between the 12th and 30th week of age, with an onset characterized by polydipsia, glycosuria, rapid weight loss, hyperglycaemia and ketoacidosis (Table 1). The onset of hyperglycaemia is preceded by insulitis, progressive B-cell destruction and decreasing circulating insulin levels leading to insulin dependency [2-4]. Without insulin treatment the animals die within 4 to 8 weeks (unpublished observations). Thus, clinical and pathological features in the NOD mouse closely resemble human Type 1 (insulin-dependent) diabetes mellitus. Since all conclusions drawn from animal models are, however, based on analogy with human disease, the analogy needs detailed validation. For this reason we describe similarities and differences relating to pathogenesis and immunotherapy in the NOD mouse and human Type 1 diabetes.

\section{Genetic background}

Continued in-breeding of the strain has resulted in high genetic uniformity as shown by morphology, allele distribution of enzymes and other proteins, and immunological studies including mixed lymphocyte reaction and skin grafting [5]. Based on this, the genetic back- ground of insulitis and overt diabetes has been investigated by backcross experiments with C57BL, NZB mice and a non obese non diabetic subline (NON) of the same origin as the NOD [6-8]. The results indicate three recessive diabetogenic genes, two of which are non MHC-linked. One controls the development of severe insulitis and appears to be incompletely dominant, and the other is involved in the progression to diabetes, probably mediated by a lack of specific suppressor cells. The third, MHC linked, gene is not required for insulitis but apparently influences the autoimmune response [7]. It has been suggested that the NOD mouse has a unique class II MHC, which may lead to the autoimmune insulitis [9]. Furthermore, treat-

Table 1. Comparison of clinical features at onset of diabetes in the human and the NOD mouse

\begin{tabular}{lll}
\hline & \multicolumn{2}{l}{$\begin{array}{l}\text { Type 1 (insulin-dependent) } \\
\text { diabetes mellitus }\end{array}$} \\
\cline { 2 - 3 } & human & NOD mouse \\
\hline Weight loss & Present & Present \\
Polydipsia & Present & Present \\
Polyuria & Present & Present \\
Hyperglycaemia & $>15 \mathrm{mmol} / 1$ & $20-30 \mathrm{mmol} / 1$ \\
Ketoacidosis & Common & Less severe \\
Serum insulin & Very low & Very low \\
Outcome without insulin & Lethal & Lethal \\
Sex preponderance & Female $\geqq$ male & Female $\gg$ male \\
\hline
\end{tabular}




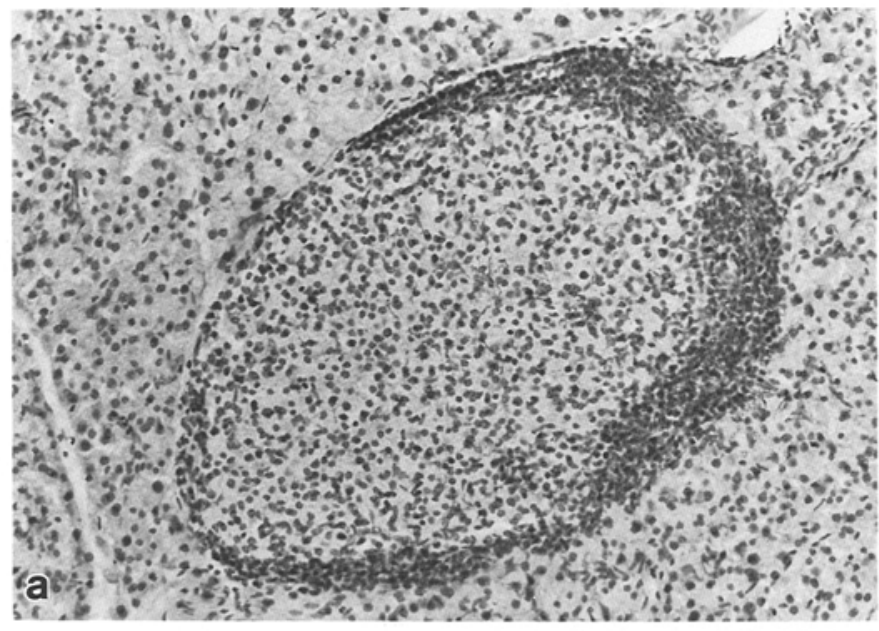

Fig. 1a and b. Micrographs of islets of Langerhans in a 20-week-old female NOD-mouse showing periinsulitis (a), followed by invasion of the islet by lymphocytes penetrating the capsule (b) (Magnification $145 \times$, haematoxylin and eosin staining)

ment with anti-I-A monoclonal antibody prevented diabetes in NOD mice [10].

Human Type 1 diabetes is associated with MHC products [11], most closely linked with the HLA DQ region [12]. In mice the equivalent to DQ-beta is the $A-\beta$ chain, and this has interesting similarities with human diabetes [13]. Back-cross experiments have shown that homozygosity at this gene is necessary for the development of diabetes. The NOD A- $\beta$ allele is unique in the species in having serine in position 57 instead of aspartic acid (Asp). Similarly in humans DQ- $\beta$ Asp 57 negative homozygosity is found in $90 \%$ of Caucasian Type 1 diabetic patients, whereas, Asp 57 positive homozygosity at DQ- $\beta$ gives almost complete protection from Type 1 diabetes [13].

Despite strong evidence for an association with a genetic factor or factors, the concordance rate for Type 1 diabetes is surprisingly low in identical twins (30-50\%), suggesting that susceptibility is inherited rather than the expressed disease [14]. The NOD mouse resembles man in this respect, since the animals are genetically identical but not all develop diabetes. Abnormal immunological parameters including islet cell antibodies (ICA) and increased numbers of circulating activated $T$ cells are, however, concordant in human twin studies $[15,16]$ and NOD mice also have a concordant immunological process, as shown by the fact that all females and more than $90 \%$ of males exhibit insulitis $[7,17,18]$. The incidence of diabetes is, however, at least twice as high in female NOD mice than in males, and castration experiments suggest that this difference is related to female sex hormones [17]. Castration of mice up to the age of 7 weeks results in an increase of diabetes incidence in males and a decrease of incidence in females.

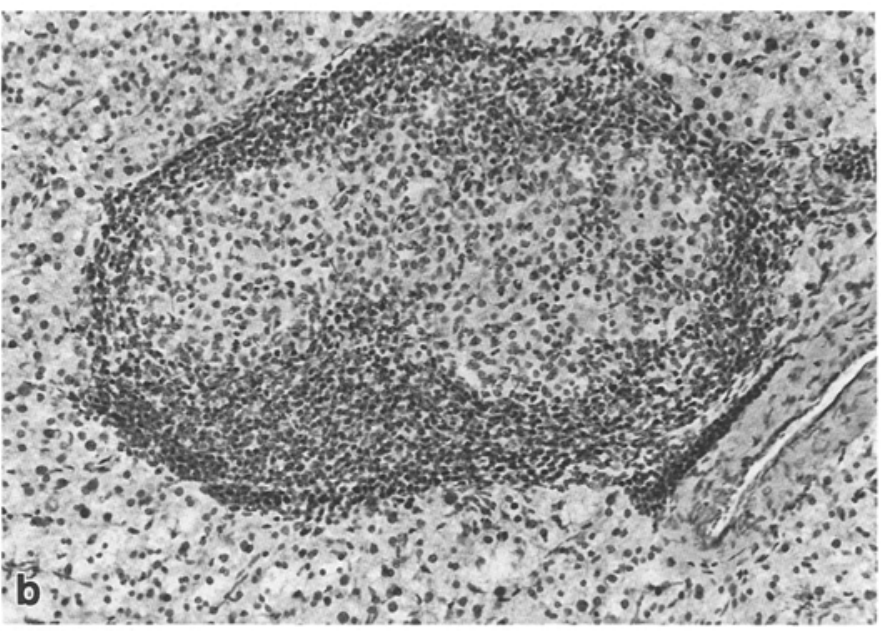

Administration of testosterone prevents diabetes in castrated animals, whereas oestradiol raises the incidence of diabetes in castrated animals of both sexes. The rate of development of diabetes is also influenced by diet [17]. Although hormonal and dietary influences have not been shown in human diabetes, human Type 1 diabetes and the NOD model suggest that genetic factors predispose to the autoimmune disorder, but have limited importance for clinical expression of the disease.

The genetic unifornity in this inbred strain has great advantages in the experimental situation as a guarantee of identity, but for the same reason has limited relevance to the human situation. Thus, even though $95 \%$ of Type 1 diabetic patients are HLA DR3 or DR4 positive [20], there is marked genetic heterogeneity. The mechanism of inheritance of the disease in the NOD mouse cannot, therefore, be identical to that in man, although it constitutes one of the possible alternatives.

\section{Histopathology}

Insulitis is the pathological hallmark recent onset Type 1 diabetes and is observed in the NOD mouse from at least the 4 th week of age $[21,22]$. The earliest change is periinsulitis adjacent to the pancreatic ducts, followed by invasion of the islet capsule by small lymphocytes which penetrate the islet (Fig. 1). The final stage is characterized by small islets from which B-cells have disappeared, with resolution of insulitis. The different stages of this process can, however, be found within the same pancreas at any age. Phenotyping of lymphocyte subsets involved in the insulitis has produced conflicting results [23-26]. We have found that monocytes and B-lymphocytes are the predominant cell population [25]. Previous studies have reported L3T4 cells (mainly helper/inducer) and MHC class-II cells as the most represented subsets [23, 26]. Within the T-lymphocyte population L3T4 cells are more frequently found than Lyt- 2 cells (mainly cytotoxic/suppressor) [24]. 
Table 2. Comparison of morphological features in human diabetes and the NOD mouse

\begin{tabular}{llc}
\hline & \multicolumn{2}{l}{$\begin{array}{l}\text { Type 1 (insulin-dependent) } \\
\text { diabetes mellitus }\end{array}$} \\
\cline { 2 - 3 } & Human & NOD mouse \\
\hline $\begin{array}{l}\text { Periinsulitis/insulitis } \\
\begin{array}{l}\text { Insulitis in subjects } \\
\text { without diabetes }\end{array}\end{array}$ & Present & Present \\
$\begin{array}{l}\text { Small islets lacking } \\
\text { B-cells at the end stages }\end{array}$ & $?$ & Present \\
$\begin{array}{l}\text { Lymphocytic infiltration } \\
\text { in other organs }\end{array}$ & Present & Present \\
\hline
\end{tabular}

The prevalence of insulitis is high in humans who have died soon after the onset of Type 1 diabetes, and in one early study insulitis was present in 16 of 23 who died within 6 months of onset $[27,28]$ and in 47 out of 60 patients with a diabetes duration of less than one year [29]. The smouldering nature of the process is equally apparent, with normal islets, insulitis and "endstage" islets depleted of B cells within the same histological field. While there is still some controversy concerning the prevalence of insulitis in man, there is agreement on the histological pattern of lymphocytic infiltration (Table 2). As in the NOD mouse, insulitis develops in man as periinsulitis and progresses to infiltration of the islets and B-cell destruction [28]. There has been only one report concerning the phenotype of lymphocyte subsets, based on the pancreas of a child who died at the time of diagnosis [30]. The majority of infiltrating lymphocytes were T-cells, predominantly CD8 positive although other inflammatory cells were present. Thus, despite possible differences between the lymphocyte subsets infiltrating the islets, the NOD mouse is a good model from the histopathological point of view. Diabetes has a strong female preponderance in the NOD mouse $(70 \%$ vs $20 \%$ at 30 weeks of age) but insulitis is present to a similar degree in both sexes. Thus, about $80 \%$ of males and $30 \%$ of females show insulitis without developing diabetes up to the 30th week of age [4]. In the human situation we remain ignorant as to the time of development of insulitis prior to the disease, although it is assumed to coincide with the appearance of ICA and other autoimmune markers, and it is not known whether individuals with insulitis inevitably progress to diabetes.

In NOD mice lymphocytic infiltration is not restricted to the islets but occurs also in salivary tissue [31] and occasionally in the thyroid and adrenal glands [32], suggesting a wider disturbance of immune tolerance in this animal. Type 1 diabetes is also associated with overt polyendocrine disease and there is an increased prevalence of autoantibodies to thyroid, adrenal or gastric parietal cells, although figures concerning this vary [33]. Infiltration of salivary glands has not, however, been described in human diabetes.

\section{Immunological observations}

\section{Autoantibodies}

ICA have been found in about $50 \%$ of NOD mice up to the 21st week of age but tend to disappear later $[34,35]$. Islet cell surface antibodies (ICSA) appear at 3-6 weeks, reach peak incidence and titre at around 12-18 weeks, and decline thereafter [26, 34]. There is no evidence that these autoantibodies are directly involved in B-cell destruction, and both ICA and ICSA might be secondary to islet cell destruction and massive release of cellular antigen, a view which accords with the time course of insulitis in this animal model. Insulin autoantibodies (IAA) have also been reported; they may antedate insulitis [35] and are present in almost all animals later in life [34]. Finally, autoantibodies which immunoprecipitate a 64.000 mol.wt.islet antigen have recently been described [36]. As in humans, the pathogenetic relevance of these autoantibodies remains uncertain, and the prognostic significance of ICA, ICSA, insulin and 64 kilodalton autoantibodies has yet to be investigated in the NOD mouse.

\section{Cell mediated immunity}

Several successful attempts have been made to transfer insulitis and diabetes via lymphocytes derived from NOD mice, using a variety of protocols. Diabetes appears within a few weeks of lymphocyte transfusion, providing further support for the autoimmune hypothesis. Recipient animals were either newborn or very young normal NOD mice [37], totally irradiated NOD mice [38, 39], or athymic nude mice of NOD origin [40]. Despite these differences, similar results were obtained with regard to the age of lymphocyte donors, and $100 \%$ successful transfer of diabetes/insulitis can only be achieved with lymphocytes from mice at least 16-19weeks-old [37, 39]. Interestingly the transfer can be made with either diabetic or non-diabetic donor lym-

Table 3. Comparison of immunological features of Type 1 (insulindependent) diabetes in humans and the NOD mouse

\begin{tabular}{lll}
\hline & \multicolumn{2}{l}{ Type 1 diabetes mellitus } \\
\cline { 2 - 3 } & Human & NOD mouse \\
\hline $\begin{array}{l}\text { Insulin autoantibodies } \\
\text { Islet cell antibodies }\end{array}$ & Present & Present \\
$\begin{array}{l}\text { Islet cell surface antibodies } \\
\begin{array}{l}\text { Islet cell specific } \\
\text { cellular immunity }\end{array}\end{array}$ & $\begin{array}{l}\text { Present } \\
\text { Present }\end{array}$ & $\begin{array}{l}\text { Present } \\
\text { Present }\end{array}$ \\
$\begin{array}{l}\text { Majormal T-helper/T-suppressor } \\
\text { in the insulitis }\end{array}$ & Present & Present \\
$\begin{array}{l}\text { Aberrant expression of } \\
\text { class II MHC on } \\
\text { insulin positive cells }\end{array}$ & Present & Present \\
\hline
\end{tabular}


phocytes. In older non-diabetic recipients (i.e. $>25$ weeks) the transfer is much less effective and only 5 of 16 developed diabetes [39]. When separated lymphocyte subsets were used, both Lyt- $2^{+}$(mainly cytotoxic/suppressor) and $\mathrm{L} \mathrm{T} 4^{+}$(mainly helper/inducer) cells appeared to be necessary. In addition, both subsets should be derived from a donor of appropriate age (16 to 19 weeks) as shown in transfer experiments in which $\mathrm{L} 3 \mathrm{~T}^{+}{ }^{+}$cells from an appropriate donor were reconstituted with Lyt $2^{+}$cells from a 6-week-old donor (or vice versa) but failed to induce diabetes when transferred. It was further shown that newborn mice are susceptible to transfer until the 3 rd week (females) and the 5 th week (males).

The NOD mouse, therefore, appears susceptible to the transfer of diabetes until the time at which insulitis develops spontaneously. At approximately 16 to 19 weeks the animals acquire the ability to transfer the disease with lymphocytes, but this capacity is often lost in non-diabetic mice from the 25 th week onwards. These findings may reflect time dependent differences in the development of necessary lymphocyte subsets (i.e. Thelper/inducer first, antigen-specific effector second and T-suppressor cells, last). If this is the case B-cells might disappear too rapidly for the induction of T-suppressor cells in animals which develop diabetes, whereas animals with slower destruction of B cells may produce sufficient specific $T$-suppressor cell activity to protect themselves from further B-cell loss.

A variety of cellular cytotoxicity systems have been investigated in search of an active effector cell mechanism in the NOD mouse. Direct cellular cytotoxicity (CTL) was increased as compared to ICR mice using $\mathrm{Balb} / \mathrm{c}$ islets as targets in a chromium release assay. Antibody dependent cellular cytotoxicity (ADCC) and natural killer (NK) cell activity have been tested in NOD and ICR mice. Both ADCC against chicken erythrocytes in the presence of anti-chicken erythrocyte antibodies and NK activity against Chang liver cells are decreased in the NOD mouse [41]. Another interesting observation is that athymic nude mice with NOD background [40] or NOD mice undergoing neonatal thymectomy [18] did not develop insulitis and diabetes - suggesting a pivotal role for T-lymphocytes in the autoimmune process. Administration of monoclonal antibodies $(\mathrm{mAb})$ specific to some lymphocyte surface markers can block function or destroy the corresponding cell subset. Thus, treatment with anti Thy $1.2 \mathrm{mAb}$ (T cells) prevents diabetes but does not influence the progression of insulitis [40]. Administration of L3T4 $\mathrm{mAb}$ abolishes insulitis and diabetes $[42,43]$. In addition, Lyt $2^{+}$cells (suppressor/cytotoxic) and macrophages are necessary for the development of insulitis since treatment with anti-Lyt 2 antibody and silica particles prevents B-cell destruction [44].

Thus, macrophages and $\mathrm{Lyt} 2^{+}$cells are required for induction of the autoimmune process by appropriate antigen presentation and for generation of specific ef- fector cells, respectively. On the other hand, cyclophosphamide (known to impair T-suppressor cells) promotes overt diabetes and increases its incidence in the NOD mouse [45]. These data suggest the presence of specific T-suppressor cells in the NOD mouse, although these are clearly not efficient enough to maintain tolerance in all cases.

Aberrant expression of HLA class II on B cells has been claimed to play an important role in the initiation of the autoimmune process leading to diabetes [46]. Class II expression was found in a child who died soon after clinical presentation [30] and confirmed by an immunohistological study of formalin fixed paraffin embedded tissue from post mortem cases with recent onset of diabetes [47]. In the NOD mouse conflicting results have been obtained. Hanafusa et al. [48] described aberrant expression of class II molecules prior to insulitis, as identified by anti-IA mouse antibodies, not only in the NOD but also to some extent in BALB/C and B10.GD mice. These results could not be confirmed using $\mathrm{P} 7 / 7$ rat $\mathrm{MAb}$ [23] which recognizes class-II molecules of b, $\mathrm{d}$ and $\mathrm{k}$ haplotype [49], and all islet cells appear negative with this antibody [25].

\section{Immunotherapy}

Cyclosporin A reduces insulitis in the NOD mouse but is unable to abolish it [50], while ICSA titres were similar or even higher than in control animals. In another report low-dose cyclosporin treatment has been shown to protect against insulitis [51]. These data indicate that cyclosporin A can partially suppress the cell mediated reaction but not the production of ICSA. Unfortunately the incidence of diabetes in cylcosporin treated animals was not investigated.

Nicotinamide, an inhibitor of poly-ADP-ribose synthetase, reduces the incidence of insulitis and diabetes in the NOD mouse [52]. Cyclophosphamide increases the incidence of diabetes but this effect can be blocked by nicotinamide [19]. ADCC is naturally elevated in the NOD mouse but falls after nicotinamide treatment [53]. This suggests an important role for ADCC and also indicates that nicotinamide has immunomodulatory properties. This is supported by the observation that single injections of nicotinamide prior to allogeneic islet transplantation prolong graft survival, a treatment which was much more successful if nicotinamide was combined with desferroxamine, an iron-chelating agent [54]. Nicotinamide seems to have some benefit in newly diagnosed Type 1 diabetic patients $[55,56]$ and increases C-peptide secretion in the first year after diagnosis [57].

\section{Conclusion}

The NOD mouse model shares a number of important characteristics with human Type 1 diabetes. The disease develops spontaneously and is not accompanied by 
general immunodeficiency as in the BB rat. Differences include simultaneous lymphocytic infiltration of salivary glands and other organs, and a strong female predominance. Even so, study of mechanisms involved in insulitis, B-cell destruction, and the generation of other immunological disturbances allows hypotheses concerning human Type 1 diabetes to be developed and tested. The availability of high and low incidence lines may, in addition, offer clues to factors involved in the onset of diabetes.

Insulitis is in progress well before overt hyperglycaemia in the NOD mouse, and this is important for two reasons: (1) it allows the autoimmune process to be defined before complete B-cell destruction and hyperglycaemia have occurred. This might prove very useful in the search for new markers during this crucial phase of the natural history. (2) the prolonged and well defined prodromal period provides an excellent opportunity to test different approaches to immunotherapy early in the prediabetic stage.

Acknowledgements. This work was supported by grants from the Joint Research Board of St. Bartholomew's Hospital London, UK (E.L., P.P.) and CNR "Progetti Bilaterale" Programme Italy-UK grant no.88.00617.04. A.S. is a fellow of the Juvenile Diabetes Foundation (USA).

\section{References}

1. Tochino Y (1986) Discovery and breeding of the NOD mouse. In: Tarui S, Tochino Y, Nonaka K (eds) Insulitis and type I diabetes - lessons from the NOD mouse. Academic Press, New York London, pp 3-10

2. Ohneda A, Kobayashi T, Nihei J, Tochino Y, Kanaya H, Makino S (1984) Insulin and glucagon in spontaneously diabetic nonobese mice. Diabetologia 27: 460-463

3. Kolb H (1987) Mouse models of insulin dependent diabetes: lowdose streptozotocin-induced diabetes and nonobese diabetic (NOD) mice. Diab Metab Rev 3: 751-778

4. Tochino T (1987) The NOD mouse as a model of Type 1 diabetes. CRC Crit Rev Immunol 8: 49-81

5. Komeda K, Goto N (1986) Genetic monitoring of the NOD mouse. In: Tarui $S$, Tochino Y, Nonaka $K$ (eds) Insulitis and type I diabetes - Lessons from the NOD mouse. Academic Press New York London, pp 11-22

6. Makino S, Hayashi $Y(1986)$ Genetic analysis for insulitis in the NOD mouse. In: Tarui S, Tochino Y, Nonaka K (eds) Insulitis and type I diabetes - lessons from the NOD mouse. Academic Press, New York London, pp 23-31

7. Wicker LS, Miller BJ, Coker LZ, McNally SE, Scott S, Mullen Y, Appel MC (1987) Genetic control of diabetes and insulitis in the nonobese diabetic (NOD) mouse. J Exp Med 165: 1639-1654

8. Prochazka M, Leiter EH, Serreze DV, Coleman DL (1987) Three recessive loci required for insulin-dependent diabetes in nonobese diabetic mice. Science 237: 286-289

9. Nishimoto H, Kikimoto T, Yamamura KI, Kishimoto T (1987) Prevention of autoimmune insulitis by expression of I-E molecules in NOD mice. Nature 328: 432-444

10. Boitard C, Bendelac A, Richard MF, Bach JF (1988) Prevention of diabetes in nonobese diabetic mice by anti-I-A monoclonal antibodies: transfer of protection by splenic T cells. Proc Natl Acad Sci USA 85: 9719-9723

11. Nerup J, Platz P, Andersen OO, Christy M, Lyngsoe J, Poulsen JE, Ryder LP, Nielsen LS, Thomsen M, Svejgaard A (1974) HLA antigens and diabetes mellitus. Lancet II: 864-866
12. Lernmark $\AA$, Li S, Baekkeskov S, Christie M, Michelsen B, Ursing J, Olsson ML, Sundkvist G (1987) Islet-specific immune mechanisms. Diab Metab Rev 3:959-980

13. Todd JA, Bell JI, McDevitt HO (1987) HLA-DQ beta gene contributes to susceptibility and resistance to insulin-dependent diabetes mellitus. Nature 329: 599-604

14. Barnett AH, Eff C, Leslie RDG, Pyke DA (1981) Diabetes in identical twins. Diabetologia 20: 87-93

15. Johnston C, Pyke DA, Cudworth AG, Wolf E (1983) HLA-DR typing in identical twins with insulin-dependent diabetes: differences between concordant and discordant pairs. Br Med J 286: 253-255

16. Wolf E, Spencer KM, Cudworth AG (1983) The genetic susceptibility to Type 1 (insulin-dependent) diabetes analysis of the HLA-DR association. Diabetologia 24: 224-230

17. Leiter EH, Prochazka M, Coleman DL (1987) Animal model of human disease - the non-obese diabetic mouse. Am J Pathol 128: 380-383

18. Ogawa M, Maruyama T, Hasegawa T, Kanaya T, Kobayashi F, Tochino Y, Uda H (1985) The inhibitory effect of neonatal thymectomy on the incidence of insulitis in non-obese diabetes (NOD) mice. Biomed Res 6: 103-105

19. Nakajima H, Tarui S, Tochino Y (1986) Clues to the pathogenesis of diabetes in the NOD mouse based on preventive approaches. In: Tarui S, Tochino Y, Nonaka $\mathrm{K}$ (eds) Insulitis and type I diabetes - lessons from the NOD mouse. Academic Press, New York London, pp 181-186

20. Maclaren NK (1988) How, when and why to predict IDDM. Diabetes 37: 1591-1594

21. Fujita T, Yui R, Kusumoto Y, Serizawa Y, Makino S, Tochino (1982) Lymphocytic insulitis in a non-obese diabetic (NOD) strain of mice: an immunohistochemical and electron microscope investigation. Biomed Res 3: 429-443

22. Fujino-Kurihara M, Fujita $H$, Hakura A, Nonaka T, Tarui $S$ (1985) Morphological aspects on pancreatic islets of non-obese diabetic (NOD) mice. Virchows Arch B 49: 107-120

23. Signore A, Cooke A, Pozzilli P, Butcher G, Simpson E, Beverley PCL (1987) Class II and IL2 receptor positive cells in the pancreas of NOD mice. Diabetologia 30: 902-905

24. Miyazaki A, Hanafusa T, Yamada K, Miyagawa J, Fujino-Kurihara H, Nakajima H, Nonaka K, Tarui S (1985) Predominance of T lymphocytes in pancreatic islets and spleen of prediabetic non obese diabetic (NOD) mice: a longitudinal study. Clin Exp Immunol 60: 622-630

25. Signore A, Gale EAM, Andreani D, Beverley PCL, Pozzilli P (1989) The natural history of lymphocyte subsets infiltrating the pancreas of NOD mice. Diabetologia 32: 282-289

26. Kanazawa Y, Komeda K, Sato S, Mori S, Akanuma K, Takaku F (1984) Non-obese-diabetic mice: immune mechanisms of pancreatic B-cell destruction. Diabetologia 27: 113-115

27. Gepts W (1965) Pathologic anatomy of the pancreas in juvenile diabetes mellitus. Diabetes 14: 619-633

28. Gepts W (1987) Islet morphologic changes in diabetes. Diab Metab Rev 3: 859-872

29. Foulis AK, Liddle CN, Farquharson MA, Richmond JA, Weir RS (1986) The histopathology of the pancreas in Type 1 (insulin-dependent) diabetes mellitus: a 25 -year review of death in patients under 20 years of age in the United Kingdom. Diabetologia 29: 267-274

30. Bottazzo GF, Dean BM, McNally J, Hackay EH, Swift PGF, Gamble DR (1985) In situ characterization of autoimmune phenomena and expression of HLA molecules in the pancreas in diabetic insulitis. N Engl J Med 313: 353-360

31. Miyagawa J, Hanafusa T, Miyazaki A, Yamada K, Fujino-Kurihara $\mathrm{H}$, Nakajima $\mathrm{H}$, Kono $\mathrm{N}$, Nonaka $\mathrm{K}$, Tochino $\mathrm{Y}$, Tarui S (1986) Ultrastructural and inımunocytochemical aspects of lymphocytic submandibulitis in the non-obese diabetic (NOD) mouse. Virchows Arch B 51: 215-225

32. Asamoto H, Oishi M, Akazawa Y, Tochino Y (1986) Histological and immunological changes in the thymus and other organs in NOD mice. In: Tarui S, Tochino Y, Nonaka K (eds) Insulitis and 
type I diabetes - lessons from the NOD mouse. Academic Press, New York London, pp 61-71

33. Eisenbarth GS, Rassi N (1983) The polyglandulare failure syndromes. In: Davis TF (ed) Autoimmune endocrine disease. John Wiley \& Sons, New York, pp 193-206

34. Reddy S, Bibby NJ, Elliot RB (1988) Ontogeny of islet cell antibodies, insulin autoantibodies and insulitis in the non-obese diabetic mouse. Diabetologia 31: 322-328

35. Pontesilli O, Carotenuto P, Gazda LS, Pratt PF, Prowse SJ (1987) Circulating lymphocyte populations and autoantibodies in nonobese diabetic (NOD) mice: a longitudinal study. Clin Exp Immunol 70: 84-93

36. Atkinson MA, MacLaren NK (1988) Autoantibodies in nonobese diabetic mice immunoprecipitate $64,000-\mathrm{M}_{\mathrm{r}}$ islet antigen. Diabetes 37: 1587-1590

37. Bendelac A, Carnaud C, Boitard C, Bach JF (1987) Syngenic transfer of autoimmune diabetes from diabetic NOD mice to healthy neonates. J Exp Med 166: 823-832

38. Miller BJ, Appel MC, O'Neil JJ, Wicker LS (1988) Both the Lyt$2^{+}$and $\mathrm{L} 3 \mathrm{~T} 4{ }^{+} \mathrm{T}$ cell subset are required for the transfer of diabetes in nonobese diabetic mice. J Immunol 140:52-58

39. Wicker LS, Miller BJ, Mullen Y (1986) Transfer of autoimmune diabetes mellitus with splenocytes from nonobese diabetic (NOD) mice. Diabetes 35: 855-860

40. Harada M, Makino S (1986) Immunological manipulation of diabetes production in NOD mice. In: Tarui S, Tochino Y, Nonaka K (eds) Insulitis and type I diabetes - lessons from the NOD mouse. Academic press, New York London, pp 143-153

41. Maruyama T, Takei I, Taniyama M, Katoaka K, Matsuki S (1984) Immunological aspect of non-obese diabetic mice: immune islet cell killing mechanism and cell-mediated immunity. Diabetologia 27: $121-123$

42. Koike T, Itoh Y, Ishii T, Ito I, Takabayashi K, Maruyama N, Tomioka $\mathrm{H}$, Yoshida S (1987) Preventive effect of monoclonal antiL3T4 antibody on development of diabetes in NOD mice. Diabetes 36: 539-541

43. Wang Y, Hao L, Gill RG, Lafferty KJ (1987) Autoimmune diabetes in NOD mouse is L3T4 T-lymphocyte dependent. Diabetes 36: $535-538$

44. Charlton B, Bacelj A, Mandel TE (1988) Administration of silica particles or anti-Lyt2 antibody prevents beta-cell destruction in NOD mice given cyclophosphamide. Diabetes 37: 930-935

45. Harada M, Makino S (1984) Promotion of spontaneous diabetes in non-obese diabetes-prone mice by cyclophosphamide. Diabetologia 27 : 604-606

46. Bosi E, Todd I, Pujol-Borrell R, Bottazzo GF (1987) Mechanisms of autoimmunity: relevance to the pathogenesis of Type I diabetes. Diabetes Metab Rev 3: 893-928

47. Foulis AK, Farquharson MA, Hardman R (1987) Aberrant expression of class II major histocompatibility complex molecules by B cells and hyperexpression of class I major histocompatibility complex molecules by insulin containing islets in Type 1 (insulindependent) diabetes mellitus. Diabetologia 30: 333-343

48. Hanafusa T, Fujino-Kurihara H, Miyazaki A, Yamada K, Nakajima H, Miyagawa J, Kono N, Tarui S (1987) Expression of class II major histocompatibility complex antigens on pancreatic $B$ cells in the NOD mouse. Diabetologia 30: 104-148

49. Momburg F, Koch N, Moller P, Moldenhauser G, Butcher G, Hammerling GJ (1986) Differential expression of Ia and Ia-associated invariant chain in mouse tissues after in vivo treatment with IFN-gamma. J Immunol 136: 940-948

50. Kida K, Kaino Y, Miyagawa $T$, Gotoh $Y$, Matsuda $H$, Kono $T$ (1986) Effect of cyclosporin on insulitis and ICSA in NOD mice. In: Tarui $\mathrm{S}$, Tochino $\mathrm{Y}$, Nonaka $\mathrm{K}$ (eds) Insulitis and Type 1 diabetes - lessons from the NOD mouse. Academic Press, New York London, pp 137-142

51. Formby B, Miller N, Garret R, Peterson CM (1987) Effects of low-dose cyclosporine prophylaxis in nonobese diabetic mice. $\mathrm{J}$ Pharm Exp Ther 241: 1106-1111

52. Yamada $\mathrm{K}$, Nonaka $\mathrm{K}$, Hanafusa $\mathrm{T}$, Miyazaki A, Toyoshima $\mathrm{H}$, Tarui S (1982) Preventive and therapeutic effects of large-dose nicotinamide injections on diabetes associated with insulitis - an observation in non obese diabetic (NOD) mice. Diabetes 31: $749-753$

53. Nakajima $H$, Yamada $K$, Hanafusa $T$, Fujino-Kurihara $H$, Miyagawa J, Miyazaki A, Saito R, Minami Y, Kono N, Nonaka Tochino Y, Tarui S (1986) Elevated antibody-dependent cellmediated cytotoxicity and its inhibition by nicotinamide in the diabetic NOD mouse. Immunol Lett 12: 91-94

54. Nomikos IN, Prows SJ, Carotenuto P, Lafferty KJ (1986) Combined treatment with nicotinamide and desferrioxamine prevents islet allograft destruction in NOD mice. Diabetes 35: 1302-1304

55. Vague $P$, Vialettes B, Lassman-Vague V, Vallo J (1987) Nicotinamide may extend remission phase in insulin-dependent diabetes. Lancet I: $619-620$

56. Mendola G, Casamitjana R, Gomis R (1989) Effect of nicotinamide therapy upon B-cell function in newly diagnosed Type 1 (insulin-dependent) diabetic patients. Diabetologia 32:160-162

57. Pozzilli P, Visalli N, Ghirlanda G, Manna R, Andreani D (1989) Nicotinamide increases $C$ peptide secretion in patients with newly-diagnosed Type 1 (insulin-dependent) diabetes. Diabetic Med 6: 568-572

Dr. P.Pozzilli

Department of Diabetes and Immunogenetics

St. Bartholomew's Hospital

West Smithfield

London EC1A 7BE

UK 